\title{
PENERAPAN MODEL PEMBELAJARAN THINK PAIR SHARE UNTUK MENINGKATKAN AKTIVITAS BELAJAR SISWA DI KELAS V SD NEGERI NO. 056614 SIDOREJO
}

\author{
Kamaliah \\ Guru Mata Pelajaran PKn di SD Negeri No. 056614 Sidorejo \\ Surel : Kamaliah12@gmail.com
}

\begin{abstract}
The Implementation Of Learning Think Pair Share Model To Improve The Student Activities Class V SD Negeri No. 056614 Sidorejo Second Semester T.A 2015/2016. This research aims to improve students' learning activities using Cooperative Learning Model Think Pair Share in class V SD Negeri No. 056614 Sidorejo. These research subjects are 28 students. The study lasted for two cycles can be concluded that 1) Activities of student learning through the implementation of the Cooperative Learning Think Pair Share model is based on observations of the two observers increased from the first cycle to the second cycle. 2) The results of student learning through the implementation of the Cooperative Learning Think Pair Share model increases from the first cycle to the second cycle.
\end{abstract}

Keywords: Learning Think Pair Share Model, Student Activities

\begin{abstract}
Abstrak : Penerapan Model Pembelajaran Think Pair Share Untuk Meningkatkan Aktivitas Belajar Siswa Di Kelas V SD Negeri No. 056614 Sidorejo Semester Genap T.A 2015/2016. Penelitian ini bertujuan untuk meningkatkan aktivitas belajar siswa dengan menggunakan model pembelajaran Thnik Pair Share di kelas V SD Negeri No. 056614 Sidorejo. Subjek penelitian ini berjumlah 28 orang siswa. Penelitian berlangsung selama dua siklus dapat disimpulkan bahwa 1) Aktivitas belajar siswa melalui penerapan model pembelajaran Thnik Pair Share berdasarkan pengamatan kedua pengamat mengalami peningkatan dari siklus I ke siklus II. 2) Hasil belajar siswa melalui penerapan model pembelajaran Thnik Pair Share meningkat dari siklus I ke siklus II.
\end{abstract}

Kata Kunci: Model Pembelajaran Think Pair Share, Aktivitas Siswa

\section{PENDAHULUAN}

Tugas seorang guru dalam menyampaikan materi pelajaran kepada siswa tidaklah mudah. Guru harus memiliki berbagai kemampuan yang dapat menunjang tugasnya agar tujuan pendidikan dapat dicapai. Salah satu kemampuan yang harus dimiliki oleh seorang guru dalam meningkatkan kompetensi profesinya ialah kemampuan mengembangkan model pembelajaran.

Dalam mengembangkan model pembelajaran seorang guru harus dapat menyesuaikan antara model yang dipilihnya dengan kondisi siswa, materi pelajaran, dan sarana yang ada. Oleh karena itu, guru harus menguasai beberapa jenis model pembelajaran agar proses belajar mengajar berjalan lancar dan tujuan yang ingin dicapai dapat terwujud.

Masalah utama dalam pembelajaran Pendidikan Kewarganegaraan (PKn) ialah belum tepatnya penggunaan metode atau model pembelajaran dalam menyampaikan materi pelajaran, yang memenuhi muatan tatanan nilai, agar dapat diinternalisasikan pada diri siswa serta mengimplementasikan hakekat pendidikan nilai dalam kehidupan mereka sehari-hari. Hal ini berkaitan dengan kritik masyarakat terhadap materi pelajaran PKn yang tidak 
Jurnal Guru Kita (JGK). Vol 1 (2) Maret 2017, hlm. 128-134

bermuatan nilai-nilai praktis tetapi hanya bersifat politis atau alat indoktrinasi untuk kepentingan kekuasaan pemerintah. Strategi pembelajaran dalam Proses Belajar Mengajar (PBM) terkesan sangat kaku, kurang fleksibel, kurang demokratis, dan guru cenderung lebih dominan (one way method). Di samping masih menggunakan model konvensional yang monoton, aktivitas guru lebih dominan daripada siswa, akibatnya guru seringkali mengabaikan proses pembinaan tatanan nilai, sikap, dan tindakan, sehingga mata pelajaran PKn tidak dianggap sebagai mata pelajaran pembinaan warga negara yang menekankan pada kesadaran akan hak dan kewajiban tetapi lebih cenderung menjadi mata pelajaran yang jenuh dan membosankan.

\section{Berdasarkan pengalaman}

peneliti sampai sekarang masalah yang dihadapi dalam mengajarkan mata pelajaran PKn adalah kurangnya minat belajar, siswa, kuarang tepatnya metode pembelajaran yang digunakan yakni metode ceramah sehingga mengakibatkan siswa sering ribut di dalam kelas dan mengantuk.

Untuk meminimalkan permasalahan tersebut maka guru harus menggunakan model pembelajaran yang dapat menciptakan suasana belajar yang melibatkan siswa bekerja secara gotong royong yaitu dengan menggunakan model pembelajaran kooperatif. Salah satu model pembelajaran Kooperatif yakni model pembelajaran tipe Think Pair Share. Model pembelajaran Think Pair Share Kooperatif tipe TPS (Think-pair-Share) digunakan untuk mengajarkan isi akademik atau untuk mengetahui sejauh mana pemahaman siswa terhadap suatu materi pelajaran yang diajarkan. Guru menciptakan interaksi yang mendorong rasa ingin tahu, ingin mencoba, bersikap mandiri dan ingin maju. Guru memberikan suatu informasi yang mendasar saja sebagai dasar pemikiran bagi anak didik dalam mencari dan menemukan sendiri informasi lainnya.

Berdasarkan latar belakang yang telah diuraikan di atas, maka yang menjadi pokok masalah dalam penelitian ini dapat dirumuskan sebagai berikut; 1) Apakah penerapan model pembelajaran kooperatif tipe Think Pair Share dapat meningkatkan hasil belajar siswa pada materi pokok memahami kebebasan berorganisasi di kelas V SD Negeri No. 056614 Sidorejo T.A 2015/2016?; 2) Apakah penerapan model pembelajaran kooperatif tipe Think Pair Share dapat meningkatkan aktivitas belajar siswa pada materi pokok memahami kebebasan beroganisasi di kelas V SD Negeri No. 056614 Sidorejo T.A 2015/2016?;

Sehingga merujuk pada rumusan masalah maka penelitian ini ditujukan untuk; 1) Untuk mengetahui apakah penerapan model pembelajaran kooperatif tipe Think Pair Share dapat meningkatkan hasil belajar siswa pada materi pokok memahami kebebasan berorganisasi di kelas V SD Negeri No. 056614 Sidorejo T.A 2015/2016; 2) Untuk mengetahui apakah penerapan model pembelajaran kooperatif tipe Think Pair Share dapat meningkatkan aktivitas belajar siswa pada materi pokok memahami kebebasan berorganisasi di kelas V SD Negeri No. 056614 Sidorejo T.A 2015/2016;

Kooperatif tipe TPS (Thinkpair-Share) digunakan untuk mengajarkan isi akademik atau untuk mengetahui sejauh mana pemahaman siswa terhadap suatu materi pelajaran yang diajarkan. Guru menciptakan 
interaksi yang mendorong rasa ingin tahu, ingin mencoba, bersikap mandiri dan ingin maju. Guru memberikan suatu informasi yang mendasar saja sebagai dasar pemikiran bagi anak didik dalam mencari dan menemukan sendiri informasi lainnya.

Model pembelajaran kooperatif tipe TPS (Think-Pair-Share) ini memberikan siswa kesempatan untuk bekerja sendiri serta bekerjasama dengan orang lain. Kelas disusun dalam kelompok yang terdiri dari 2-4 orang siswa dengan kemampuan heterogen. Maksud kelompok yang heterogen adalah yang terdiri dari campuran siswa dengan jenis kelamin, suku, dan kemampuan siswa yang berbedabeda.Hal ini bermanfaat untuk melatih siswa agar berani mengajukan pendapat, ataupun menerima pendapat dan bekerjasama dengan teman yang berbeda latar belakangnya. Model TPS (Think-Pair-Share) ini memberi kesempatan sedikitnya delapan kali lebih banyak kepada setiap siswa untuk dikenali dan menunjukan partisipasi mereka kepada orang lain, dalam memecahkan suatu permasalahan".

Kooperatif type Think-PairShare (TPS) memiliki prosedur yang diterapkan secara eksplisit (tidak berbelit-belit) untuk memberi siswa waktu yang lebih banyak dengan berfikir, menjawab dan saling membantu satu sama lainnya.

\section{METODE}

Penelitian ini dilakukan di SD Negeri No. 056614 Sidorejo dan pelaksanaannya pada bulan Februari 2016 sampai dengan Juni 2016.

Subjek dalam penelitian ini adalah seluruh siswa kelas V SD Negeri No. 056614 Sidorejo dengan jumlah siswa yang terikut dalam penelitian ini sebanyak 28 orang.

Alat pengumpul data dalam penelitian ini adalah; 1) tes hasil belajar; 2) lembar aktivitas belajar siswa;

Penelitian ini menggunakan Penelitian Tindakan Kelas (PTK). PTK adalah suatu bentuk kajian yang bersifat reflektif oleh pelaku tindakan yang dilakukan untuk meningkatkan kemantapan rasional dari tindakan mereka dalam melaksanakan tugas, memperdalam pemahaman terhadap tindakan-tindakan yang dilakukan itu, serta memperbaiki kondisi dimana praktek pembelajaran tersebut dilakukan.

Sesuai dengan jenis penelitian yang dipilih, yaitu penelitian tindakan, maka penelitian ini menggunakan model penelitian tindakan dari Kemmis dan Taggart (dalam Sugiarti, 1997:6), yaitu berbentuk spiral dari sklus yang satu ke siklus yang berikutnya. Setiap siklus meliputi planning (rencana), action (tindakan), observation (pengamatan), dan reflection (refleksi). Langkah pada siklus berikutnya adalah perencanaan yang sudah direvisi, tindakan, pengamatan, dan refleksi. Sebelum masuk pada siklus I dilakukan tindakan pendahuluan yang berupa identifikasi permasalahan

Metode Analisis Data pada penelitian ini digunakan metode deskriptif dengan membandingkan hasil belajar siswa sebelum tindakan dengan hasil belajar siswa setelah tindakan.

Langkah-langkah pengolahan data sebagai berikut:

1. Merekapitulasi nilai pretes sebelum tindakan dan nilai tes akhir Siklus I dan Siklus II

2. Menghitung nilai rerata atau persentase hasil belajar siswa sebelum dilakukan tindakan dengan 
hasil belajar setelah dilakukan tindakan pada Siklus I dan Siklus II untuk mengetahui adanya peningkatan hasil belajar.

Sebagai tolak ukur keberhasilan penelitian tindakan kelas ini dapat dilihat hasil belajar yang dikonfirmasi dengan kriteria ketuntasan minimal (KKM) PKn untuk kelas V SD Negeri No. 056614 Sidorejo sebesar 70, jika hasil belajar siswa mencapai KKM secara individual dan $\geq 85 \%$ jumlah siswa memperoleh nilai $\geq \mathrm{KKM}$ maka pembelajaran tuntas secara klasikal.

\section{PEMBAHASAN}

Berikut ini akan dijelaskan kondisi awal siswa kelas $\mathrm{V}$ yang menyangkut hasil belajar siswa pada mata pelajaran PKn. Untuk mempertegas identifikasi tersebut dilakukan pretes terhadap kelas V. Dari tes awal diperoleh nilai terendah 30 dan tertinggi 60. Dengan rata-rata 42,1 dan KKM 70 maka ketuntasan klasikal 0\% sehingga dapat disimpulkan bahwa kemampuan awal siswa dalam materi pembelajaran sangat rendah. Meski dapat dipahami karena siswa belum mempelajari materi tersebut di sekolah, namun juga menggambarkan bahwa kepedulian siswa untuk membaca materi baru di rumah masih rendah.

Observasi menghasilkan data aktivitas belajar siswa yang belum begitu menunjukkan siswa aktif diskusi. Data hasil observasi aktivitas belajar siswa disajikan dalam Tabel .1.

\section{Tabel Skor Aktivitas Belajar Siswa}

Siklus I

\begin{tabular}{|c|l|c|c|}
\hline No & \multicolumn{1}{|c|}{ Aktivitas } & Skor & Proporsi \\
\hline 1 & $\begin{array}{l}\text { Menulis, } \\
\text { membaca }\end{array}$ & 15 & $38 \%$ \\
\hline 2 & Mengerjakan & 13.75 & $34 \%$ \\
\hline
\end{tabular}

\begin{tabular}{|c|l|c|c|} 
& LKS & & \\
\hline 3 & $\begin{array}{l}\text { Bertanya pada } \\
\text { teman }\end{array}$ & 3 & $8 \%$ \\
\hline 4 & $\begin{array}{l}\text { Bertanya pada } \\
\text { guru }\end{array}$ & 3 & $8 \%$ \\
\hline 5 & $\begin{array}{l}\text { Yang tidak } \\
\text { relevan }\end{array}$ & 5.25 & $13 \%$ \\
\hline \multicolumn{2}{|c|}{ Jumlah } & 40 & $100 \%$ \\
\hline
\end{tabular}

Merujuk pada Tabel aktivitas dominan yang dilakukan siswa adalah menulis dan membaca (38\%) kondisi ini belum sesuai dengan yang diharapkan karena seharusnya aktivitas diskusi lebih dominan ketimbang aktivitas individual tersebut, sementara aktivitasi mengerjakan LKS dalam posisi kedua (34\%), bertanya pada guru (8\%) atau siswa masih sangat bergantung pada guru. Dan aktivitas bertanya pada teman dan yang tidak relevan berturut-turut $8 \%$ dan $13 \%$.

Pada akhir proses belajar mengajar siswa diberi tes Formatif I dengan tujuan untuk mengetahui tingkat keberhasilan siswa dalam proses belajar mengajar yang telah dilakukan. Adapun data hasil formatif pada Siklus I ditunjukkan Tabel.

Tabel Distribusi Hasil Formatif 1

\begin{tabular}{|c|c|c|}
\hline Nilai & Frekunsi & Rata-rata \\
\cline { 1 - 2 } 60 & 13 & \multirow{2}{*}{75} \\
\cline { 1 - 2 } 80 & 9 & \\
\cline { 1 - 2 } 100 & 6 & \\
\cline { 1 - 2 } Jumlah & 28 & \\
&
\end{tabular}

Merujuk pada Tabel tersebut, nilai terendah Formatif I adalah 60 dan tertinggi adalah 100. Merujuk pada KKM sebesar 70 maka hanya 15 dari 28 orang siswa mendapat nilai ketuntasan atau ketuntasan klasikal tercapai sebesar $53 \%$. Nilai ini berada di bawah kriteria ketuntasan klasikal sebesar $85 \%$ sehingga dapat dikatakan KBM Siklus I 
gagal memberi ketuntasan belajar dalam kelas. Nilai rata-rata kelas adalah 75 masih di bawah KKM. Dengan demikian maka peneliti berusaha melakukan tindakan perbaikan dalam melaksanakan pembelajaran Siklus II yang dirasa perlu.

Dari pengamatan dan analisis hasil belajar siswa pertemuan 1 dan pertemuan 2 pada siklus I rata-rata hasil belajar siswa adalah 75,0. Sejumlah 15 orang siswa telah tuntas belajar pada batas KKM, sejumlah 13 orang siswa lainnya masih belum tuntas menurut batas KKM. Nilai tertinggi adalah 100 dan nilai terendah 60. Hasil tersebut menunjukkan bahwa pada siklus I secara klasikal siswa belum tuntas belajar, karena siswa yang memahami materi yang telah disampaikan hanya sebesar 54\% lebih kecil dari persentase ketuntasan yang dikehendaki yaitu sebesar $85 \%$. Hal ini disebabkan karena siswa masih merasa baru dan belum mengerti apa yang dimaksudkan dan digunakan guru dengan menerapkan model pembelajaran kooperatif tipe think pair share

Observasi yang dilakukan dua guru sejawat menghasilkan data aktivitas belajar siswa Siklus II yang mengalami perbaikan dibandingkan Siklus sebelumnya. Data hasil observasi aktivitas belajar siswa disajikan dalam Tabel.

Tabel Skor Aktivitas Belajar Siswa Siklus II

\begin{tabular}{|c|l|c|c|}
\hline No & \multicolumn{1}{|c|}{ Aktivitas } & Skor & Proporsi \\
\hline 1 & $\begin{array}{l}\text { Menulis, } \\
\text { membaca }\end{array}$ & 13.25 & $33 \%$ \\
\hline 2 & $\begin{array}{l}\text { Mengerjakan } \\
\text { LKS }\end{array}$ & 17.25 & $43 \%$ \\
\hline 3 & $\begin{array}{l}\text { Bertanya pada } \\
\text { teman }\end{array}$ & 6 & $15 \%$ \\
\hline 4 & Bertanya pada & 2.75 & $7 \%$ \\
\hline
\end{tabular}

\begin{tabular}{|c|l|c|c|} 
& guru & & \\
\hline 5 & $\begin{array}{l}\text { Yang tidak } \\
\text { relevan }\end{array}$ & 0.75 & $2 \%$ \\
\hline Jumlah & 40 & $100 \%$ \\
\hline
\end{tabular}

Merujuk pada Tabel aktivitas dominan yang dilakukan siswa adalah mengerjakan LKS (43\%) kondisi ini telah sesuai dengan yang diharapkan karena seharusnya aktivitas kerja memang lebih dominan ketimbang aktivitas individual menulis dan membaca yang berada pada peringkat kedua (33\%), bertanya pada guru turun menjadi (7\%) atau siswa mulai mandiri. Hal ini diperkuat dengan aktivitas bertanya pada teman dan yang tidak relevan berturut-turut (15\%) dan (7\%).

Pada akhir proses belajar mengajar Siklus II siswa diberi tes Formatif II dengan tujuan untuk mengetahui tingkat keberhasilan siswa dalam proses belajar mengajar yang telah dilakukan. Adapun data hasil formatif pada Siklus II ditunjukkan Tabel.

\section{Tabel Distribusi Hasil Formatif II}

\begin{tabular}{|c|c|c|}
\hline Nilai & Frekunsi & Rata-rata \\
\hline 60 & 3 & \multirow{2}{*}{86.4} \\
\cline { 1 - 2 } 80 & 13 & \\
\cline { 1 - 2 } 100 & 12 & \\
\cline { 1 - 2 } Jumlah & 28 & \\
\hline
\end{tabular}

Merujuk pada Tabel tersebut nilai terendah Formatif II adalah 60 dan tertinggi adalah 100. Merujuk pada KKM sebesar 70 maka 25 dari 28 orang siswa mendapat nilai ketuntasan atau ketuntasan klasikal tercapai sebesar $89 \%$. Nilai ini berada di atas kriteria ketuntasan klasikal sebesar $85 \%$ sehingga dapat dikatakan KBM Siklus II berhasil memberi ketuntasan belajar dalam kelas. Nilai rata-rata kelas adalah 86,4 telah mencapai KKM. Dengan demikian maka penelitian telah berhasil 
Jurnal Guru Kita (JGK). Vol 1 (2) Maret 2017, hlm. 128-134

memberi ketuntasan klasikal dalam dua siklus.

Penerapan model pembelajaran think pair share (TPS) pada pembelajaran PKn siklus II telah dapat meningkatkan hasil belajar siswa. Hasil belajar pada siklus II rata-rata 86,4 nilai terendah 60 dan nilai tertinggi 100 . Ketuntasan kelas telah melampaui batas minimal > 85\% yaitu sebesar $89 \%$. Dengan demikian hasil ini dapat dianggap bahwa pembelajaran dengan model pembelajaran think pair share (TPS) telah dapat meningkatkan hasil belajar siswa. Beberapa catatan perbaikan selama proses pembelajaran diketahui :

1. Dalam pelaksanaan proses pembelajaran siswa sudah mulai aktif.

2. Siswa mulai membiasakan diri bertanya baik pada teman ataupun pada guru.

3. Peneliti memberi perhatian lebih pada siswa yang sebelumnya dianggap kurang disiplin selama proses belajar.

Merujuk pada data di atas dapat dilihat bahwa nilai rata-rata sebelum penerapan model pengajaran think pair share pada mata pelajaran PKn yaitu berupa nilai pretes adalah 42,1 dengan ketuntasan belajar yang dicapai $0 \%$, setelah penerapan model pengajaran think pair share nilai siswa mengalami peningkatan. Berdasarkan hasil tes pada siklus I, nilai rata-rata hasil belajar yang dicapai siswa adalah 75,0 dengan persentasi $54 \%$, untuk nilai rata-rata hasil belajar dan persentasi ketuntasan klasikal yang dicapai belum mencapai indikator keberhasilan yang ditetapkan. Merujuk pada tabel yang sama, hasil tes pada siklus II menunjukkan nilai ratarata hasil belajar yang dicapai siswa adalah 86,4 dengan persentasi mencapai yaitu $89 \%$. Hasil belajar tersebut sudah mencapai indikator yang ditetapkan yaitu sekurang-kurangnya $85 \%$ hasil belajar siswa sudah mencapai nilai minimal 70. Secara keseluruhan hasil belajar siswa mengalami peningkatan dari pra pembelajaran, siklus I sampai akhir siklus II. Namun hasil pembelajaran diakhir siklus I masih ada 13 orang siswa memperoleh nilai di bawah ketuntasan. Hal ini terjadi karena disebabkan beberapa faktor diantaranya adalah sebagai berikut.

a. Beberapa siswa belum memahami peran dan tugasnya dalam bekerja kelompok karena belum terbiasa dengan model pembelajaran yang diterapkan.

b. Interaksi antar siswa belum berjalan dengan baik karena siswa belum terbiasa untuk menyampaikan pendapatnya kepada sesama teman lainnya dalam menyelesaikan masalah.

c. Adanya siswa yang pasif dan menggantungkan permasalahan yang dihadapi kepada kelompoknya.

Uraian di atas menyatakan bahwa pada siklus I meski sebagian indikator keberhasilan telah tercapai namun terdapat 12 siswa belum tuntas nilainya. Oleh karena itu perlu adanya suatu tindakan pada siklus II agar hasil belajar siswa dapat ditingkatkan dan mencapai indikator keberhasilan dengan ketuntasan klasikal mencapai maksimum. Tindakan yang diberikan berupa pembimbingan pada masingmasing kelompok dibatasi oleh waktu yang telah ditetapkan merata untuk semua kelompok, guru menganalisis kembali kemampuan penerapan model dan materi ajar dengan memperkirakan kesulitan-kesulitan yang akan dihadapi 
siswa dan jalan keluar langsung yang dapat ditempuh ditengah KBM berlangsung Hasil belajar siswa diakhir siklus II telah mencapai ketuntasan klasikal $89 \%$ yang berarti seluruh siswa telah memperoleh nilai tuntas. Dengan demikian tindakan yang diberikan pada siklus II telah berhasil memberikan perbaikan hasil belajar pada siswa. Hal ini dipengaruhi beberapa faktor diantaranya adalah sebagai berikut:

a. Siswa telah terbiasa dengan bekerja secara kelompok.

b. Keberanian siswa untuk berinteraksi berjalan dengan baik karena siswa sudah mulai terbiasa untuk bertanya dan menyampaikan pendapatnya kepada sesama teman lainnya dalam menyelesaikan masalah.

c. Siswa mulai aktif dan tahu akan tugasnya sehingga tidak menggantungkan permasalahan yang dihadapi kepada teman dalam kelompoknya.

\section{KESIMPULAN}

Adapun kesimpulan dari penerapan model pembelajaran kooperatif tipe TAI selama kegiatan belajar mengajar pada mata pelajaran ekonomi di kelas XII IPS-3 SMA Negeri 1 Percut Sei Tuan sebagai berikut :

1. a. Data aktivitas siswa rata-rata menurut pengamatan pengamat pada Siklus I antara lain menulis/membaca (38\%), mengerjakan LKS (29\%), bertanya sesama teman (8\%), bertanya kepada guru (17\%), dan yang tidak relevan dengan $\mathrm{KBM}(7 \%)$.

b. Data aktivitas siswa rata-rata menurut pengamatan pada Siklus II antara lain membaca (33\%), mengerjakan LKS (38\%), bertanya sesama teman (20\%), bertanya kepada guru (7\%), dan yang tidak relevan dengan KBM (3\%). Sehingga terjadi perbaikan aktivitas belajar siswa dalam dua siklus.

2. Hasil belajar siswa dengan menerapkan model pembelajaran kooperatif tipe TAI pada Formatif I menunjukkan rata-rata 72 dengan ketuntasan klasikal $47 \%$ dan Formatif II menunjukkan rata-rata 82 dengan ketuntasan secara klasikal $87 \%$ atau mencapai ketuntasan secara kalsikal dengan peningkatan ketuntasan klasikal $40 \%$.

\section{DAFTAR RUJUKAN}

Ibrahim, Muhsin. Dkk. (2000). Pembelajaran Kooperatif. Surabaya: University Press.

Kamaliah. (2016). Meningkatkan Hasil Belajar PKn Siswa Melali Model Pembelajaran Kooperatif Think Pair Share di Kelas V SD Negeri No. 056614 Sidorejo Semester Genap T.A 2015/2016. (PTK Karangan Sendiri).

Lie, Anita. 2005. Cooperative Learning Mempraktikkan Cooperative Learning di Ruang-ruang

Kelas. Jakarta : PT. Gramedia Widiarsarana Indonesia.

Lie, Anita. 2000. Cooperatif Learning. Jakarta. Alfabeta: Grafindo.

Mukhlis, Abdul. (Ed). 2000. Penelitian Tindakan Kelas. Makalah Panitian Pelatihan Penulisan Karya Ilmiah untuk Guru-guru sekabupaten Tuban.

Sugiarti, Titik. 1997. "Motivasi Belajar". Jakarta: Cerdas Pustaka. 